Molekul, Vol. 14. No. 1, Mei 2019: 56 - 63

\title{
MOLEKUL
}

\section{ACE Inhibitory and Antioxidative Bioactive Peptides Derived from Hydrolyzed Soy Milk}

\author{
Sandra Hermanto ${ }^{1 *}$, Annisa Septiana ${ }^{1}$, Deni K Putera ${ }^{1}$, Fitriah Hatiningsih² ${ }^{2}$ Anna Muawanah ${ }^{1}$ \\ 'Department of Chemistry, Faculty of Science and Technology. \\ Syarif Hidayatullah State Islamic University, Jakarta Indonesia 15412 \\ ${ }^{2}$ Center for Integrated Laboratory, Syarif Hidayatullah State Islamic University, \\ Jakarta Indonesia 15412 \\ *Corresponding author email: hermantokimia@uinjkt.ac.id
}

Received 25 Mar 2019; Accepted 28 May 2019; Available online 5 Jun 2019

\begin{abstract}
Soy milk is a soybean processed product rich in protein as well as sources of bioactive peptides. Bioactive peptides defined as specific protein fragments that have a positive impact on body functions and conditions and may ultimately influence health. This study was conducted to explore the potential of hydrolyzed soy milk as a source of antioxidative and antihypertensive bioactive peptides through enzymatic hydrolysis. The initial treatment of soy milk protein was acidic precipitation with hydrochloric acid. Furthermore, protein precipitate was hydrolyzed using pepsin proteolytic enzyme with an enzyme: substrate ratio (1:5, 1:10 and 1:20). Protein hydrolysis was carried out for $0-48$ hours at $37^{\circ} \mathrm{C}$ in an acetate buffer $\mathrm{pH}$ 4.5. The soy milk protein hydrolysates were subjected to determination of \% DH (Degree of Hydrolysis) and protein profile by SDS-PAGE (sodium dodecyl sulphate polyacrylamide gel electrophoresis). The antihypertensive assay was carried out by in vitro inhibition of the ACE enzyme (Angiotensin Converting Enzyme) and antioxidative activity assay using the DPPH method. The results showed that the optimum conditions for hydrolysis of soy milk were obtained at 40 hours with a $\%$ DH value of $53.24 \%$ in enzyme ratio $1: 20$ and the highest antihypertensive activity was obtained from 48 hours hydrolysis with \% ACE inhibition value of $79.31 \%$. The highest antioxidative activity of bioactive peptide was obtained at hydrolysis 48 hours with $\mathrm{IC}_{50}$ $69.1034 \mu \mathrm{g} / \mathrm{ml}$. After fractionated and LCMS characterized it was obtained 2 bioactive peptides with molecular weights of 8.954 and 2,696 kDa. These bioactive peptides from hydrolyzed of soymilk might be potential as an antihypertensive agent and reduce oxidative stress.
\end{abstract}

Keywords: Antihypertensive, antioxidative, soy milk, enzymatic hydrolysis, pepsin, ACE inhibitor

\section{INTRODUCTION}

Research on natural antioxidants in plant foods has become a trend of the last three decades. This is because some of synthetic antioxidants such as BHA and BHT, are triggering to be a carcinogenic in the high doses. On the other hand, the availability of natural antioxidant sources is still limited. Exploration of natural sources of antioxidants continues today as human awareness of the harmful effects of free radicals on stress oxidative. Over the past several decades research shown that some proteins derived from plant food products have the potential source of antioxidants (Dominic Agyei \& Sarethy, 2015).

One of the plant foods that are rich in antioxidative agent is soybeans. Soybeans are one of plants that are widely cultivated and consumed in the world, especially in Asia. Several types of soybeans have been known to have several natural antioxidant-producing agents because they are rich in phenolic compounds (Scalbert, Johnson, \& Saltmarsh, 2005). Besides that soybeans also has several important nutrients including protein and bioactive peptides (Huang, Davidge, \& Wu, 2013). Park, Lee, Baek, \& Lee (2010), have reported a strong anti oxidative agent from soy protein hydrolysates obtained by alkalase hydrolysis with low molecular mass (MWCO $<3 \mathrm{kDa}$ ). Several other studies have shown that bioactive antioxidative peptides are rich in hydrophobic amino acids such as phenylalanine, alanine and proline (Elias, Kellerby, \& Decker, 2008). The study conducted by Roblet et al., (2012) by ultrafiltration of soy protein hydrolysates resulted from dual enzymatic hydrolysis (pepsin and pancreatin) produced peptides with relatively high anti oxidative capacity.

Soybeans are also rich of antihypertensive bioactive peptides. Fermented soy products, such as traditional food (soy sauce and tempeh), have been known to be one of the important sources of antihypertensive peptide that producing ACE inhibitors (Cha \& Park, 2005); (Shimakage, Shinbo, \& Yamada, 2012). Other antihypertensive peptides of the soybean food products are Korean "chunggugjang" 
soy products obtained from soybean fermentation with Bacillus subtilis CH-1023 (Korhonen \& Pihlanto, 2003). Antihypertensive peptides have also been identified, among others in soybean paste (Shin et al., 2001), soy sauce (Okamoto et al. 1995); (Nakahara et al., 2010) natto and tempe (Gibbs, Zougman, Masse, \& Mulligan, 2004) and other soybean fermentation products (Ibe et al., 2009). (Tomatsu, Shimakage, Shinbo, Yamada, \& Takahashi, 2013), has produced eight antihypertensive agents obtained from soy protein hydrolyzate through protease hydrolysis (PROTIN SD-NY10).

Soybeans have enormous potential as alternatives of natural antioxidants and antihypertensive agents. However, soybeans have some limitations such as unpleasant taste for some food products, and also contain raffinose and stachyose which cannot be digested by humans (Park et al., 2010). This can be reduced by processing soybeans through fermentation process or other soybean processing by converting soybeans to soy milk (Subrota, Shilpa, Brij, Vandna, \& Surajit, 2013). Soy milk is rich in nutrients and has a number of proteins, iron, unsaturated fatty acids and high niacin, but low in fat, carbohydrates, calcium. Low levels of saturated fat and cholesterol in soy milk can reduce the risk of heart disease (Kim, et al.,, 2006)

Research on soy milk protein hydrolysates is currently still limited. The potential of bioactive peptides produced from soybean protein allows of the soy protein soluble in soy milk can be used as antioxidative and antihypertensive agents. In this study isolation of bioactive peptides from local soy milk with a focus on studies on extraction, purification and characterization of bioactive peptides. Hydrolysis of protein is carried out by pepsin as a proteolytic enzyme. The basis for selecting of enzyme because pepsin is one of the easily available enzyme and some of soy protein hydrolysates will produce bioactive peptides through the digestion by this enzyme (Gibbs et al., 2004); (Meinlschmidt, Sussmann, Schweiggert-Weisz, \& Eisner, 2016).

In order to produce bioactive peptides that have potentially antioxidative and antihypertensive agents, the hydrolysis time and enzyme / substrate ratio are important variables that must be considered. In this study optimization of the hydrolysis process will be carried out by varying the hydrolysis time and the composition of the substrate enzymes ratio (Lee, Kim, Ryu, Shin, \& Lim., 2004). Analysis of antioxidant activity was carried out by using of radical scavenging assay of DPPH and ACE (Angiotensine Converting Enzyme) inhibitory test for antihypertensive agent. Finally, this research expected to obtain hydrolysates of soy milk as a source of bioactive peptide which have benefit as antioxidative and antihypertensive agents in necessary to reduce of stress oxidative in our body.

\section{EXPERIMENTAL SECTION}

\section{Raw Materials and Chemicals}

Soy milk obtained from local supermarkets in the Jakarta region, hydrochloric acid, acetic buffer, pepsin
(Porcine gastric mucosa, from Sigma Aldrich (USA), the ACE (Angiotensin Converting Enzyme, rabbit lung) from Sigma Aldrich Chemical Co. (USA). N-Hippuryl-His-Leu (Hydrate Powder) $\geq 98 \%$ (HPLC grade), BSA solution (Bovin Serum Albumin) sigma, PBS (phosphate buffered saline) silver nitrate for staining solutions. DPPH (1,1dipheny 1-2-picrylhydrazyl), sodium dodecyl sulfate (SDS) $10 \%$; Lowry I and Lowry II solutions, Acrylamide solution gel $(30 \% \mathrm{~T}$; 2.67C) (Bio-Rad) Bis-acrylamide, Resolving Buffer (Tris-HCl $1.5 \mathrm{M}$ pH 8.8 Bio-Rad); Stacking Buffer (Tris-HCl $0.5 \mathrm{M}$ pH 6.8 Bio-Rad); Ammonium peroxide disulfate (APS) $10 \%$; N, N, N 'Tetramethylethylenediamine (TEMED) (Sigma Aldrich); Running buffer Sigma; Staining solution Coomassie blue R250 Bio-Rad; Phosphate buffer 0.25M pH 7.4, methanol $(\mathrm{MeOH})$ and acetonitrile $(\mathrm{ACN})$ grade liquid chromatography-mass spectrometry (LC-MS) from SigmaAldrich. Formic acid (FA) was obtained from Grüssing (Filsum, Germany), Sephadex G-10; Medium Cas No. 9050-68-4 (Sigma-Aldrich).

\section{Precipitation of soy milk protein}

Precipitation of soy milk protein $(450 \mathrm{~mL})$ was carried out by adding of $1 \mathrm{~N} \mathrm{NaOH}$ to $\mathrm{pH} 8.5$, stirred by a magnetic stirrer for 30 minutes, then centrifuged at $5600 \mathrm{~g}$ for 20 minutes. The supernatant was separated in a beaker and $1 \mathrm{~N} \mathrm{HCl}$ is added to $\mathrm{pH}$ 4.5. The solution then centrifuged again at $5600 \mathrm{~g}$ for 20 minutes, the supernatant was removed and the protein deposits were collected and dried and weighed.

\section{Enzymatic hydrolysis of soy milk protein}

Pepsin as much as $1 \mathrm{mg}$ (3200-4500 units/mg of protein) was added to protein extract with a ratio of protein : enzyme (20:1) (10:1) and (5:1), and hydrolysis was carried out in acetate buffer at $37{ }^{\circ} \mathrm{C}$ and $\mathrm{pH} 4.5$ (Meinlschmidt et al., 2016). During the incubation process, as much as $5 \mathrm{ml}$ of the mixture was taken at intervals of $0,4,8,16,24,36,40$ and 48 hours and the degree of hydrolysis was calculated using the Alder Nissen method (Adler-Nissen, 1986). After incubation process is complete, each of hydrolysates mixture is based by adding $0.5 \mathrm{M} \mathrm{pH} 8$ Tris- $\mathrm{HCl}$ and heated at $98{ }^{\circ} \mathrm{C}$ for $5-10$ minutes to inactivate the enzyme. The hydrolysates mixture stored in a dry state (freeze dry) at -20 ${ }^{\circ} \mathrm{C}$ before further use.

\section{Measurement of hydrolyzed protein}

Lowry solution consisting of $1 \mathrm{~mL}$ of solution A $(20 \mathrm{mM}$ $\mathrm{CuSO}_{4} .5 \mathrm{H}_{2} \mathrm{O}$ and $30 \mathrm{mM} \mathrm{Na}$-citrate) and $50 \mathrm{~mL}$ of solution $\mathrm{B}\left(0.1 \mathrm{M} \mathrm{Na} \mathrm{CO}_{3}\right.$ and $\left.0.1 \mathrm{M} \mathrm{NaOH}\right)$ were prepared, then homogenized with vortex and allowed to stand for 10 minutes. Folin ciocalteu $1 \mathrm{~N}$ was added to the reaction mixture, homogenized with vortex and incubated for 30 minutes. The reaction mixture was measured at $\lambda 750 \mathrm{~nm}$ and the hydrolysate of protein level was determined by using the bovine serum albumin (BSA) as standard (Lowry, et. al., 1951)

\section{Determination of Degree of Hydrolysis}


A total of $20 \mathrm{mg}$ of protein hydrolysate are added to TCA (trichloroacetic acid) $10 \%(\mathrm{~b} / \mathrm{v})$. The mixture was then incubated for 30 minutes for precipitation, then centrifuged $(7,800 \mathrm{~g}$, for 15 minutes). Supernatant was analyzed for soluble protein content by Lowry method. The degree of hydrolysis was calculated by the following formula (Adler-Nissen, 1986):

$$
\% \mathrm{DH}=\frac{(\mathrm{TCA} \text { soluble protein } 10 \%)}{(\text { total protein sample })} \times 100 \% .
$$

Determination of protein degradation by SDS-PAGE

The distribution of hydrolysates molecular weight of samples was determined according to Laemmli method using SDS-PAGE under reducing conditions (Laemmli, 1970). The samples were suspended with $1 \times$ Tris- $\mathrm{HCl}$ sample buffer $(0.125 \mathrm{~mol} \mathrm{~L}-1$ Tris- $\mathrm{HCl}, 4 \% \mathrm{SDS}, 20 \% \mathrm{v} / \mathrm{v}$ Glycerol, 0.2 mol L-1 DTT, $0.02 \%$ bromophenol blue, $\mathrm{pH}$ 6.8 ), boiled for $5 \mathrm{~min}$ to cleave non-covalent bonds and centrifuged at $12,100 \mathrm{~g}$ for $10 \mathrm{~min}$. The electrophoresis was performed on 4-20\% Mini protean gels electrophoresis and the proteins were separated in electrophoresis conditions of $200 \mathrm{~V} 100 \mathrm{~mA}, 120$ minutes with molecular weight marker (10-250 kDa, Precision Plus Protein ${ }^{\mathrm{TM}}$ Unstained Standard, Bio-Rad Laboratories Inc., Hercules, CA, USA). Electrophoresis was performed at room temperature and protein visualization was conducted by silver stain method.

\section{Measurement of Antioxidative Activity of Peptides (DPPH scavenging)}

A total of $10 \mathrm{mg}$ in each sample was dissolved with 100 $\mathrm{mL}$ methanol $(1,000 \mathrm{ppm})$. Sample solution was diluted to the series of concentration of 320,160,80,40,20, 10 and 5 ppm. Each of diluted samples was put into a test tube and added $2 \mathrm{~mL}$ DPPH $0.002 \%$. The sample solution was mixed until homogeneous and incubated for 30 minutes in a dark room. The absorbance of the sample solution was measured by UV-Vis spectrophotometer at $520 \mathrm{~nm}$. The DPPH radical scavenging activity of the sample was compared with a reference standard, ascorbic acid. The percentage inhibition value calculated by the following formula:

$$
\% \text { Inhibition }=\frac{\text { A blank-A sample }}{\text { A sample }} \times 100
$$

The $\mathrm{IC}_{50}$ is determined using the linear regression $\mathrm{y}=\mathrm{ax}+$ $\mathrm{b}$, where $\mathrm{y}$ is $\%$ inhibition which is $50 \%$ and $\mathrm{x}$ is the sample concentration which will be determined by the $\mathrm{IC}_{50}$ value (Oliveira, et al., 2014)

\section{Measurement of ACE Inhibitory Activity}

The ACE-inhibitory activity was measured by Cushman and Cheung method (Cushman \& Cheung, 1971). The method is based on the liberation of hippuric acid from hippuryl-Lhistidyl-L-leucine (HHL) catalyzed by ACE. 15 $\mu \mathrm{L}$ sample mixed with $125 \mu \mathrm{L}$ of $7.6 \mathrm{mM}$ HHL, $100 \mathrm{mM}$

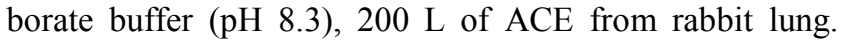
After $30 \mathrm{~min}$ of incubation at $37{ }^{\circ} \mathrm{C}$ the reaction was stopped by addition of $250 \mu \mathrm{L} 1 \mathrm{~N} \mathrm{HCl}$. The hippuric acid formed by action of ACE was extracted with ethyl acetate, and after removal of ethyl acetate by heat evaporation the amount of hippuric acid was measured spectrophotometrically at $228 \mathrm{~nm}$. The inhibitory activity of hydrolysate was expressed as percentage of ACE inhibition at a given protein concentration calculated by the following formula:

$$
\begin{aligned}
& \% \text { inhibition }=\frac{[\mathrm{C}-\mathrm{A}]}{[\mathrm{C}-B]} \times 100 \% \\
& \text { Where: } \\
& \mathrm{A}=\text { absorbance of sample } \\
& \mathrm{B}=\text { absorbance of blank solution } \\
& \mathrm{C}=\text { absorbance of control (sample replace by } \\
& \text { demineralized water) }
\end{aligned}
$$

\section{Separation and purification of protein hydrolysates}

Gel filtration chromatography was performed on Sephadex G-10 (Sigma Co., USA). The column $(2.5 \times 50$ $\mathrm{cm})$ previously equilibrated with the distilled water, operated at a flow rate of $0.2 \mathrm{ml} \mathrm{min}^{-1}$ and fraction of $2 \mathrm{ml}$ were collected and analyzed by UV-absorbance (Perkin Elmer Lambda EZ 201, USA) at $280 \mathrm{~nm}$. The samples were filtered through $0.5 \mathrm{~m}$ syringe filters prior to application to the column. The fraction with the highest antioxidant activity was further analyzed by LCMS/MS Q-TOF MS (Zhang, Wu, Ling, \& Lu, 2013)

\section{Identification of peptides molecular weight with LCMS Q-TOF ESI-MS}

Peptides with the highest antioxidative and antihypertensive activity were analyzed by using LCMS QTOF ESI-MS instruments (Waters). A certain number of samples were injected into LCMS instrument and ionized in ESI electrospray ionization mode after previously dissolved in methanol / water (1: 1, v/v). Molecular weight (MW) of peptides was analyzed from mass spectrum results through deconvolution of protein MW (Zhang, et al., 2013).

\section{RESULTS AND DISCUSSION}

The soy milk used in this study was $800 \mathrm{~mL}$ extracted from 200 grams of soybeans. 200 grams of soybeans produced protein extract as much as $72.9652 \mathrm{~g}$, so that the resulting yield was $36.48 \%$. This value was lower compared to that obtained by Park et al., (2010) where the yield was $72.35 \%$. The difference between the results obtained is probably caused by the type of soybeans used and the extraction process of soy milk which is related to the accuracy of the isoelectric point.

\section{Hydrolysis of Soy Milk Protein}

The level of soluble protein from hydrolyzed soy milk after enzymatic hydrolysis on each enzyme : substrate ratio can be seen in Figure 1. The highest level of soluble protein content was obtained in (20:1) substrate : enzyme ratio at 40 hours hydrolysis time which the level of soluble protein was $323.47 \mathrm{mg} / \mathrm{mL}$.

After hydrolysis it can be seen that the protein hydrolysates levels are increased. Increasing of protein caused by pepsin digest the peptide bonds in each protein extract to the shorter peptide fragments. To ensure the 
digesting of enzymatic activity of soy milk protein, then the soy milk protein hydrolysates was analyzed by SDS PAGE (Figure 2).

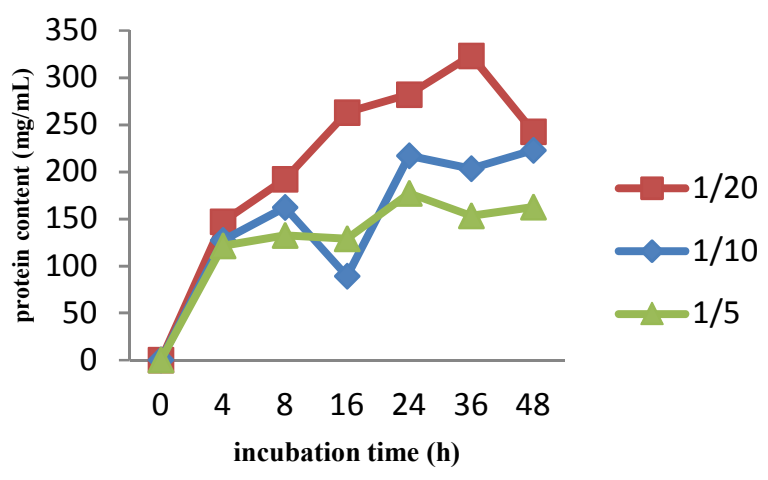

Figure 1. The level of protein content from hydrolysates of soy milk (after enzymatic hydrolysis)

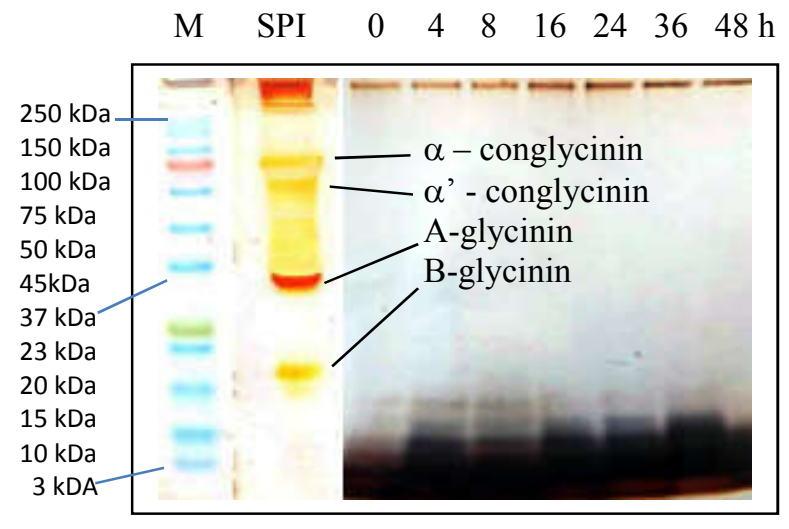

Figure 2. SDS-PAGE pattern of soy milk hydrolysate. Lane 1-7: 0-48 hours protein hydrolysates, M: protein marker, SPI : soy protein isolate.

Based on Figure 2, it was found that the thickness of soy protein isolate (SPI) and soy protein hydrolysate (1-7) produces a different bands, in which there are 4 protein bands with the highest molecular weight of protein isolate, alpha-conglicinin $(72.4 \mathrm{kDa}), \alpha^{\prime}$-conglicinin $(62.9 \mathrm{kDa})$ and acidic glycinin (29-33 kDA) and basic glycinin (17 $\mathrm{kDa}$ ) (Meinlschmidt et al., 2016). After 4 hours hydrolysis, the thickness of the protein band appeared at the molecular weight of $\sim 15 \mathrm{kDa}$ and no other protein found up than 15 $\mathrm{kDa}$, whereas at 16-48 hours the thickness of the $\mathrm{BM} \sim 15$ $\mathrm{kDa}$ protein band begins to disappear and protein bands appeared with a lower molecular weight of about $<10 \mathrm{kDa}$. It can be seen that by the longer hydrolysis time the molecular weight of the protein hydrolysates became lower, this indicates that enzymatic hydrolysis by pepsin has produced bioactive peptides with a lower molecular weight $(<10 \mathrm{kDa})$.

\section{Degree of hydrolysis (\% DH)}

The DH was continuously monitored during enzymatic treatment of SPI. In the beginning of protein hydrolysis, the large complex structured protein molecules are broken down into smaller sized peptides. As shown in Figure 3, the unhydrolyzed SPI showed an average DH value of $15.54 \%$. In the course of enzymatic hydrolysis, the DH increased significantly $(P<0.05)$. The highest DH value of $53.19 \%$ was achieved after 40 hours hydrolysis. The degree of hydrolysis is generally influenced by substrate concentration, enzyme concentration, temperature, $\mathrm{pH}$ and hydrolysis time (Meinlschmidt et al., 2016). The enzymatic hydrolysis produced protein hydrolysates containing peptides with lower molecular weights and free amino acids as usual. The decrease in the DH value occurs probably affected by external factor like temperature change and inconsistency of shaking. However, when compared to another study the value of the DH of soybean hydrolysates is still relatively greater where the hydrolysis of goat milk with the same enzyme and same conditions only produces $\% \mathrm{DH}<50 \%$ after hydrolysis for 48 hours (Lee et al., 2004)

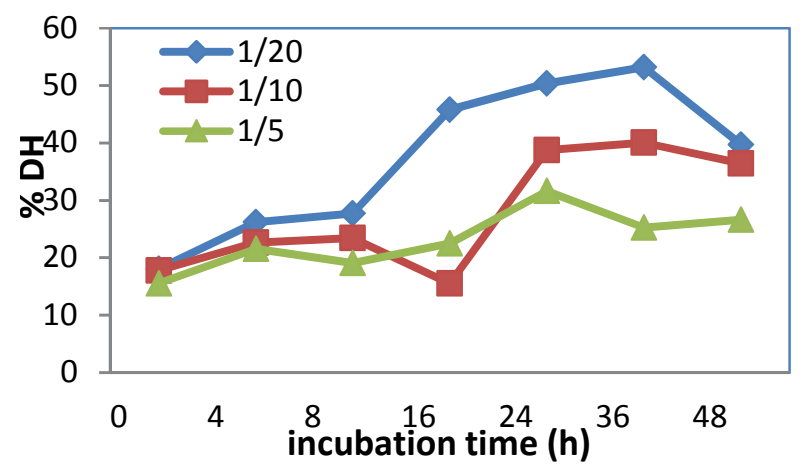

Figure 3. Degree of hydrolysis (\% DH) of soy milk protein isolate

According to Hussein, (2003) the magnitude of the \% $\mathrm{DH}$ value indicates the level of the protein hydrolysates. The high and low degree of hydrolysis is very much determined by the length of the incubation time and the concentration of the enzyme used. Enzymatic hydrolysis is more beneficial aspect because it can produce free amino acids and oligopeptides with various short chains. Pepsin is active in acidic environment with $\mathrm{pH} 2-5$ and temperatures between $37{ }^{\circ} \mathrm{C}$ and $42{ }^{\circ} \mathrm{C}$. Pepsin will digest up to $20 \%$ of the peptide bonds that enter the stomach by cutting them specifically on the C-terminal side of aromatic amino acids such as phenylalanine, tryptophan, and tyrosine (Johnston, Dettmar, Bishwokarma, Lively, \& Koufman, 2007)

ACE inhibitory activity of soy milk protein hydrolysates

Antihypertensive activity of soy milk protein hydrolysates was carried out by ACE inhibitory assays. The results of ACE inhibitory assays of soy milk hydrolysate can be seen in Figure 4. 


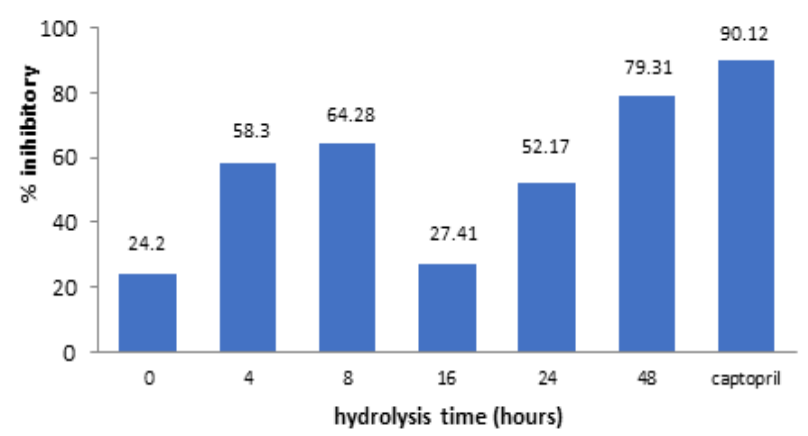

Figure 4. ACE inhibitory of soy milk protein hydrolysates

The highest ACE inhibitory of soy milk protein hydrolysates was obtained in 48 hours hydrolysis with \% inhibition of $79.31 \%$. Increasing in ACE inhibitory activity of soy milk hydrolysates comes from bioactive peptides produced during hydrolysis by the pepsin digest. This bioactive peptide will interfere with the catalytic sites of the enzyme so that ACE activity was inhibited in hydrolyzing the hippuryl-histidyl-leucine (HHL) substrate (Ryan, et al. 2011). Captopril is used as a positive control with an inhibition percentage of $90.12 \%$. Captopril is an antihypertensive drug that inhibits the formation of angiotensin I to angiotensin II by inhibiting the active side of ACE. Several previous studies stated that soy based food products showed antihypertensive effects in inhibiting angiotensin converting enzyme (ACE). ACE inhibitor peptides are found such as in soy and miso products that have been identified as nicotianamine and Ser-Trp (Okamoto, Hanagata, Kawamura, \& Yanagida, 1995)

\section{Antioxidant Activity of soy milk protein hydrolysates}

The antioxidant activity of soy milk hydrolysate was determined using DPPH method (Subrota, et al., 2013). The principle of DPPH method is radical scavenging or the interaction between antioxidants and DPPH in the form of electron transfer or hydrogen donor which can neutralize free radicals. The highest antioxidant activity was obtained at 48 hours with $\mathrm{IC}_{50}$ values of $69.12+0.9 \mu \mathrm{g} / \mathrm{mL}$ (Table 1) where all hydrolyzed soy milk protein reduced into shorter peptide fragments. Several previous studies have shown that peptides found in soybeans such as $\beta$ conglycinin, glycinin and lunasin are detected in the protein hydrolysates of soy milk with histidine amino acid residues as its main component, along with several other amino acids such as leucine, tyrosine, methionine and cysteine in general as an antioxidant by donating electrons to free radicals (Zhang et al., 2013).

Another study by Park et al., (2010) showed that antioxidative bioactive peptides obtained from soybeans were rich in hydrophobic and aromatic amino acids such as phenylalanine which be reduced to tyrosine when hydroxyl groups attacked radicals. The presence of several amino acid residues in the peptide chain can improve antioxidative properties as free radical electron scavenger. Some peptides are reported to act as chelating metal ions such as $\mathrm{Fe}^{2+}$ which can catalyze reactive oxygen that causes lipid oxidation by using the Ferric Reducing Ability of Plasma (FRAP) test method.

Table 1. Antioxidative activity of soy milk hydrolysates (0-48 hours).

\begin{tabular}{cc}
\hline Hydrolysis time & IC $_{\mathbf{5 0}}$ \\
\hline 0 hours & $92.24 \pm 0.6 \mu \mathrm{g} / \mathrm{mL}$ \\
$\mathbf{4}$ hours & $86.92 \pm 0.2 \mu \mathrm{g} / \mathrm{mL}$ \\
$\mathbf{8}$ hours & $82.41 \pm 0.3 \mu \mathrm{g} / \mathrm{mL}$ \\
$\mathbf{1 6}$ hours & $172.34 \pm 1.5 \mu \mathrm{g} / \mathrm{mL}$ \\
$\mathbf{2 4}$ hours & $186.10 \pm 2.5 \mu \mathrm{g} / \mathrm{mL}$ \\
$\mathbf{3 6}$ hours & $98.72 \pm 1.3 \mu \mathrm{g} / \mathrm{mL}$ \\
$\mathbf{4 8}$ hours & $69.12 \pm 0.9 \mu \mathrm{g} / \mathrm{mL}$ \\
\hline
\end{tabular}

Separation and purification soy milk hydrolysates with Sephadex G-10

Fractionation of hydrolyzed of soy milk derived from 48 hours hydrolysis which the highest antioxidant and antihypertensive activity was achieved. Separation and purification were carried out by Sephadex G-10 in phosphate buffer $\mathrm{pH} 7.0$ and elution rate of $0.5 \mathrm{ml} /$ minute. The fractionation result are as follows (Figure 5).

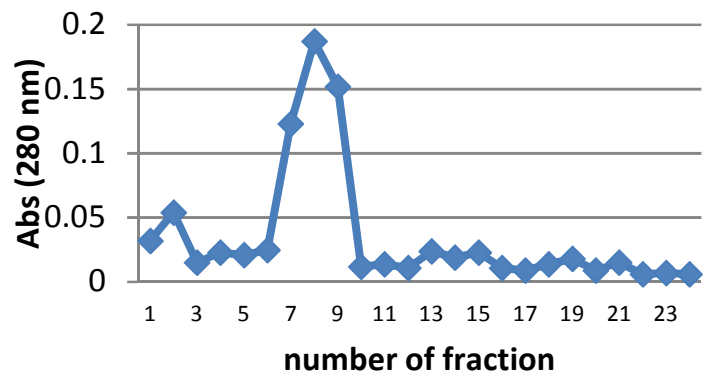

Figure 5. Fractionation of soy milk hydrolysates by Sephadex G-10

Fractionation results indicate that there are at least 3 fractions (7-9) positively contain bioactive peptides which are then determined by antioxidant activity and antihypertensive properties. The $\mathrm{IC}_{50}$ values for antioxidant activity of fraction 7-9 was $218.74 \mu \mathrm{g} / \mathrm{mL}$, while the results of antihypertensive activity $\mathrm{IC}_{50}$ value $497.25 \mu \mathrm{g} / \mathrm{mL}$ (the calculation data not shown). If we compared to the results of antioxidant and antihypertensive activity before fractionation it showed that the activity of bioactive peptide in the fraction was relatively lower than the hydrolysates. This is probably caused by some of the smaller bioactive peptides mixture are retained in the column when fractionated or some bioactive peptides are lost during the fractionation process.

Determination of molecular weight of bioactive peptides

To characterize the bioactive peptides produced from fractionation, LCMS/ESI MS analysis was then carried out. LCMS/ESI MS analysis for fraction 7-9 produced 2 chromatogram peaks as shown in Figure 6. 


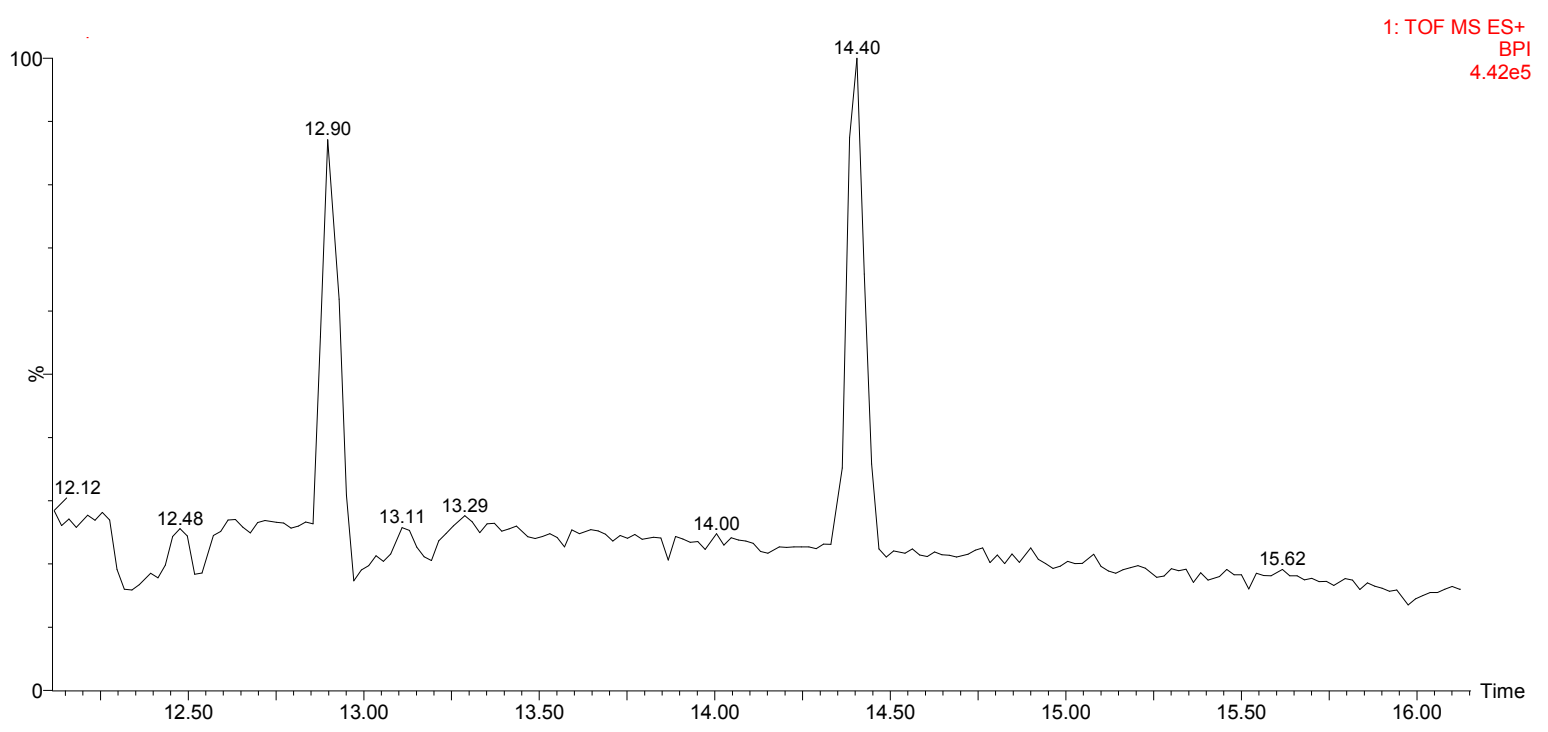

Figure 6. LCMS/ESI MS chromatogram of fraction 7-9.

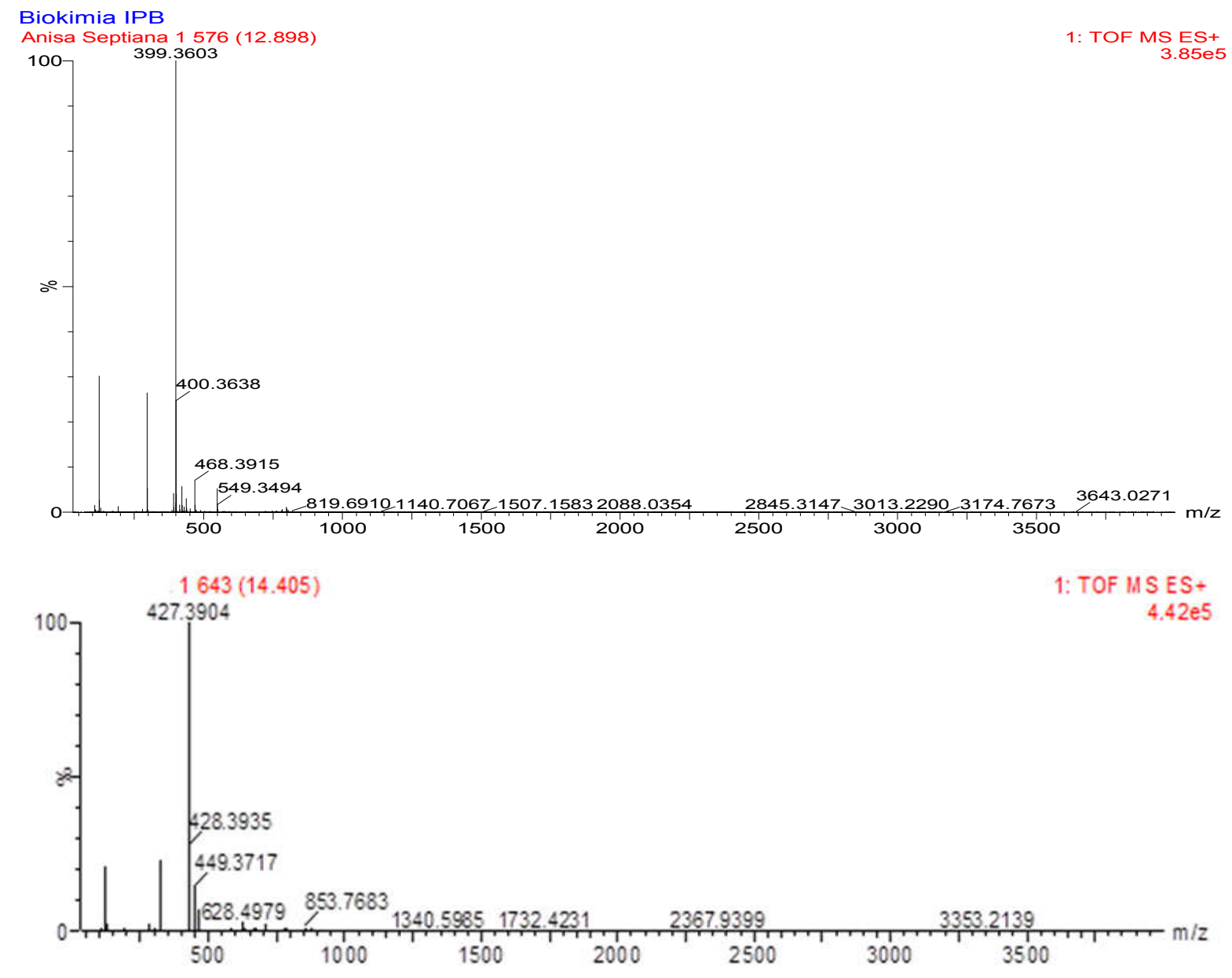

Figure 7. Mass spectrum of bioactive peptide from LCMS/ESI MS (Waters) 
It was found that are two peaks appear at 12.90 and 14.40 minutes. Each of chromatogram peak is further analyzed based on its mass spectrum. The mass spectrum of the first peptide (12.90 minutes) and the second peptide (14.40 minutes) as shown in Figure 7. Based on the results of mass spectrum analysis with deconvolution, peptide compounds at retention time 12.90 minutes has a molecular weight of $2.696 \mathrm{kDa}$ and second peptide at 14.40 minutes are thought to be peptide fragments with molecular weights $8.954 \mathrm{kDa}$.

\section{CONCLUSIONS}

Hydrolysis of soy milk by pepsin digest have been shown to produce antioxidative agents with the highest activity obtained at 48 hours hydrolysis $\left(\mathrm{IC}_{50} 69.12 \pm 0.9\right.$ $\mu \mathrm{g} / \mathrm{mL}$ ) and the highest antihypertensive activity was obtained at the same time with \% ACE inhibitory $79.8 \%$. Based on LCMS/ESI-MS analysis showed that fractionation of hydrolysates produced two peptide fragments with low molecular weight of $2.696 \mathrm{kDa}$ and $8.954 \mathrm{kDa}$. These bioactive peptides might be potential as an antihypertensive agent and reduce oxidative stress in our body.

\section{ACKNOWLEDGEMENTS}

We would like to thank the Head of Institute of Research and Community Services Syarif Hidaytullah Jakarta State Islamic University for the college development research grant in 2018. We also thank Mrs. Dewi Ferliani at Food Biotechnology Laboratory Bogor Agriculture University and the Head of the Indonesian National Police Laboratory's Forensic Laboratory for LCMS/ESI-MS analysis services.

\section{REFERENCES}

Adler-Nissen, J. (1986). Enzymic Hydrolysis of Food Protein. Elsevier Applied Science, London.

Cha, M., \& Park, J. R. (2005). Production and characterization of a soy protein-derived angiotensin I-converting enzyme inhibitory hydrolysate. Journal of Medicinal Food, 8(3), 305-310. https://doi.org/10.1089/jmf.2005.8.305

Cushman, D. W., \& Cheung, H. S. (1971). Spectrophotometric assay and properties of the angiotensin-converting enzyme of rabbit lung. Biochemical Pharmacology, 20(7), 1637-1648.

Dominic Agyei, M. K. D., \& Indira P. Sarethy, and S. P. (2015). Antioxidative Peptides Derived from Food Proteins. In \& U. C. S. Y. In V. Rani (Ed.), Free Radicals in Human Health and Disease, (pp. 417430). https://doi.org/10.1007/978-81-322-2035-0_26

Elias, R. J., Kellerby, S. S., \& Decker, E. A. (2008). Antioxidant activity of proteins and peptides. Critical Reviews in Food Science and Nutrition, 48(5), https://doi.org/10.1080/10408390701425615

Gibbs, B. F., Zougman, A., Masse, R., \& Mulligan, C.
(2004). Production and characterization of bioactive peptides from soy hydrolysate and soy-fermented food. Food Research International (Ottawa, Ont.), 37(2), 123-131. https://doi.org/10.1016/j.foodres.2003.09.010

Huang, W.-Y., Davidge, S. T., \& Wu, J. (2013). Bioactive natural constituents from food sources-potential use in hypertension prevention and treatment. Critical Reviews in Food Science and Nutrition, 53(6), 615630. https://doi.org/10.1080/10408398.2010.550071

Hussein, M. (2003). Isolation And Characterization of Soybean Protein And Whey Protein Co-Precipitates. Thesis. Department of Food Science and Agricultural Chemistry McGill University Montreal Canada.

Ibe, S., Yoshida, K., Kumada, K., Tsurushiin, S., Furusho, T., \& Otobe, K. (2009). Antihypertensive Effects of Natto, a Traditional Japanese Fermented Food, in Spontaneously Hypertensive Rats. Food Science and Technology Research, 15(2), 199-202. https://doi.org/10.3136/fstr.15.199

Johnston, N., Dettmar, P. W., Bishwokarma, B., Lively, M. O., \& Koufman, J. A. (2007). Activity/stability of human pepsin: implications for reflux attributed laryngeal disease. The Laryngoscope, 117(6), 10361039.

https://doi.org/10.1097/MLG.0b013e31804154c3

Kim, S.-L. Berhow, M. A. Kim, J.-T. Chi, H.-Y. Lee, S.-J. Chung, I.-M. (2006). Evaluation of Soyasaponin, Isoflavone, Protein, Lipid, and Free Sugar Accumulation in Developing Soybean Seeds. Journal of Agricultural and Food Chemistry, 54(26), 10003-10010.

Korhonen, H., \& Pihlanto, A. (2003). Food-derived bioactive peptides--opportunities for designing future foods. Current Pharmaceutical Design, 9(16), 12971308. Retrieved from http://www.ncbi.nlm.nih.gov/pubmed/12769738

Laemmli, U. K. (1970). Cleavage of structural proteins during the assembly of the head of bacteriophage T4. Nature, 227(5259), 680-685.

Lee, K. J., Kim, S. B., Ryu, J. S., Shin, H. S. \& Lim, J. W., (2005). Separation and Purification of Angiotensin Converting Enzyme Inhibitory Peptides Derived from Goat' s Milk Casein Hydrolysates. Asian-Aust. J. Anim. Sci. Vol 18, No. 5 : 741-746)

Lowry O H, Rosebrough N J, F. A. L. \& R. R. J. (1951). Citation Classics. J. Biol. Chem., 193(265), 87-92. https://doi.org/10.1007/978-94-007-0753-5_100521

Meinlschmidt, P., Sussmann, D., Schweiggert-Weisz, U., \& Eisner, P. (2016). Enzymatic treatment of soy protein isolates: effects on the potential allergenicity, technofunctionality, and sensory properties. Food Science and Nutrition, 4(1), 11-23. https://doi.org/10.1002/fsn3.253

Nakahara, T., Sano, A., Yamaguchi, H., Sugimoto, K., Chikata, H., Kinoshita, E., \& Uchida, R. (2010). 
Antihypertensive effect of peptide-enriched soy sauce-like seasoning and identification of its angiotensin I-converting enzyme inhibitory substances. Journal of Agricultural and Food Chemistry, 58(2), 821-827. https://doi.org/10.1021/jf903261h

Okamoto, A., Hanagata, H., Kawamura, Y., \& Yanagida, F. (1995). Anti-hypertensive substances in fermented soybean, natto. Plant Foods for Human Nutrition (Dordrecht, Netherlands), 47(1), 39-47.

Oliveira, C. F., Coletto, D., Correa, A. P. F., Daroit, D. J., Toniolo, R., Cladera-Olivera, F. and *Brandelli, A. (2014). Antioxidant activity and inhibition of meat lipid oxidation by soy protein hydrolysates obtained with a microbial protease. 21(2), 775-781.

Park, S. Y., Lee, J.-S., Baek, H.-H., \& Lee, H.G.Y.U. (2010). Purification And Characterization Of Antioxidant Peptides From Soy Protein Hydrolysate. Journal of Food Biochemistry, 34(s1), 120-132. https://doi.org/10.1111/j.1745-4514.2009.00313.x

Roblet, C. ; Amiot, J. ; Lavigne, C. ; Marette, A. ; Lessard, M. ; Jean, J.; Ramassamy, C. ; Moresoli, C. ; Bazinet, L. (2012). Screening of in vitro bioactivities of a soy protein hydrolysate separated by hollow fiber and spiral-wound ultrafiltration membranes. Food Research International, Vol.46 No., 237-249.

Scalbert, A., Johnson, I. T., \& Saltmarsh, M. (2005). Polyphenols: antioxidants and beyond. The
American Journal of Clinical Nutrition, 81(1 Suppl), 215S-217S. https://doi.org/10.1093/ajcn/81.1.215S

Shimakage, A., Shinbo, M., \& Yamada, S. (2012). ACE inhibitory substances derived from soy foods. Journal of Biological Macromolecules, 12(3), 7280.

Shin, Z. I., Yu, R., Park, S. A., Chung, D. K., Ahn, C. W., Nam, H. S., Lee, H. J. (2001). His-His-Leu, an angiotensin I converting enzyme inhibitory peptide derived from Korean soybean paste, exerts antihypertensive activity in vivo. Journal of Agricultural and Food Chemistry, 49(6), 3004-3009.

Subrota, H., Shilpa, V, Brij, S., Vandna, K. \& Surajit, M. (2013). Antioxidative activity and polyphenol content in fermented soy milk supplemented with WPC-70 by probiotic Lactobacilli. International Food Research Journal, 20(5), 2125-2131.

Tomatsu, M., Shimakage, A., Shinbo, M., Yamada, S., \& Takahashi, S. (2013). Novel angiotensin I-converting enzyme inhibitory peptides derived from soya milk. Food Chemistry, 136(2), 612-616. https://doi.org/10.1016/j.foodchem.2012.08.080

Zhang, Q. X., Wu, H., Ling, Y. F., \& Lu, R. R. (2013). Isolation and identification of antioxidant peptides derived from whey protein enzymatic hydrolysate by consecutive chromatography and Q-TOF MS. Journal of Dairy Research. https://doi.org/10.1017/S0022029913000320 